\title{
Vieira em movimento: subjacências da distinção entre tapuias, tupis e negros ${ }^{1}$
} CARLOS ZERON ${ }^{I}$

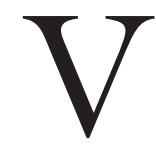

IEIRA nasceu em Portugal, em 1608, mas mudou-se para o Brasil com apenas sete anos de idade. Foi no colégio dos jesuítas de Salvador da Bahia que ele fez toda a sua formação. Ele só voltou para Portugal depois de completar 33 anos, por ocasião da restauração da monarquia. Após colecionar uma série de polêmicas servindo o rei de Portugal, Vieira foi enviado de volta ao continente americano, aos 44 anos de idade, dessa vez no Maranhão. Ali residiu entre 1653 e 1661, ano em que foi expulso com os demais jesuítas para Portugal por suas posições a respeito da escravidão indígena e da tutela política que a Companhia de Jesus deveria exercer naquela colônia portuguesa.

E, no entanto, suas posições sobre a escravidão indígena, durante o período em que viveu no Maranhão, estavam longe de ser rigoristas. Ao contrário: (a) Vieira aquiesceu com a escravidão de índios antropófagos (o que não constituía uma posição unânime entre teólogos e juristas); (b) ele consentiu também não apenas com a condição servil dos filhos de escravas, mas também de escravos, no caso de sociedades patrilineares (o que constitui outra posição diferenciada de Vieira); (c) mas, sobretudo, admitiu a redução à escravidão oriunda tanto de guerras justas como de guerras injustas, nesse último caso por meio da esdrúxula figura jurídica do "escravo de condição", que deveria servir por cinco anos. De onze situações que Vieira tipifica nas "Direções a respeito da forma que se deve ter no julgamento e liberdade no cativeiro dos índios do Maranhão", a escravidão só não seria admitida em dois casos, respeitantes ao casamento misto de índios livres e escravos (Vieira, 1951, p.28-32):

É plausível explicar essas concessões aos interesses dos conquistadores e colonizadores portugueses devido a uma relação de forças desigual entre esses e os jesuítas. De fato, as instruções reais dadas aos novos capitães-mores do Maranhão e do Grão-Pará, em 1652, determinavam que se pusessem em liberdade todos os índios cativos, conforme uma lei do mesmo ano. Temerosos da reação dos moradores, eles aguardaram quase um ano a chegada de Vieira, que vinha como superior da missão jesuíta, para proclamar a lei. Apesar dessas precauções, houve graves motins, desde fevereiro até maio de 1653, quando as câmaras de Belém e São Luís ainda se manifestavam contra o decreto real (Vieira, 1928, v.I, p.331-5). Diante disso, Vieira escreveu ao rei: “porque convém que haja os 
ditos resgates, ao menos por remir aquelas almas, o modo com que se podiam fazer justificadamente é este: [...]"; e ele prossegue sugerindo que "se nessas entradas se acharem alguns índios em cordas, ou legitimamente escravos, que esses se possam comprar e resgatar, aprovando-o primeiro os padres que forem à dita missão" (ibidem, p.310). Apenas cinco meses mais tarde, a proposta de Vieira tornou-se uma provisão real com validade não apenas para o Maranhão, mas também para São Paulo: as duas margens do império português na América entravam assim em sincronia, associando estreitamente expansão territorial e recrutamento de mão de obra escrava. No ano seguinte, 1654, Vieira fez ainda um acordo com o governador do Maranhão e os procuradores das câmaras do Estado, que regulamentava o trabalho compulsório dos índios livres dos aldeamentos, os quais realizariam seis meses de serviço por ano nas propriedades dos moradores em troca do pagamento de duas varas de pano por mês. $\mathrm{O}$ acordo ainda previa, contudo, a suspensão provisória dos resgates até a chegada de uma nova lei, que ele se dispunha a buscar em Lisboa. De volta a Portugal, Vieira obteve nova provisão real: não se fariam mais guerras contra os índios sem ordem régia; os jesuítas indicariam o cabo da escolta militar das expedições de resgate; o governo dos aldeamentos ficaria sob a superintendência dos jesuítas. Noves fora, além da contradição da lei de 1652 , jamais aplicada, a provisão real de 1655 pouco mudava os termos daquela de 1653 no que dizia respeito às condições de redução à escravidão dos índios; com essas importantes diferenças, contudo: o rei retomava o controle das guerras e outorgava a Vieira, como superior da missão jesuíta, a supervisão das expedições de descimento e a gestão dos aldeamentos. Em suma, Vieira não se opunha à escravidão dos índios, visto que contraditou o rei de Portugal ao escrever-lhe que "convém que haja os ditos resgates". Nesse sentido, ele apoiou a reivindicação dos moradores em favor da continuidade das entradas, contra a letra da lei de 1652, cuja promulgação ele deveria ter apoiado. Ao intermediar essa negociação, contudo, Vieira conseguiu inserir os jesuítas tanto nas expedições de resgate quanto no controle dos índios livres aldeados: na provisão real de 1653, os jesuítas deveriam aprovar as entradas, bem como nomear o seu capitão, junto com o governador, a Câmara, os prelados das demais religiões e o vigário geral; já na provisão de 1655, apenas os jesuítas indicariam o cabo das expedições de resgate, além de assumirem sozinhos o governo dos aldeamentos. Ou seja, com a provisão real de 1655, não se favoreciam nem os índios, cuja escravidão continuava, nem, totalmente, os moradores, que pediam a continuidade dos resgates; o que Vieira procurou obter com a nova lei foi o fortalecimento da posição dos jesuítas, tornados supervisores tanto dos resgates, quanto dos aldeamentos de índios (Zeron, 2016, p.237-40).

O balanço que o próprio Vieira fez quanto ao resultado de todas essas negociações e especificamente das orientações contidas nas suas "Direções a respeito da forma que se deve ter no julgamento e liberdade no cativeiro dos índios do Maranhão" foi bastante negativo, contudo: os 772 índios cujo cati- 


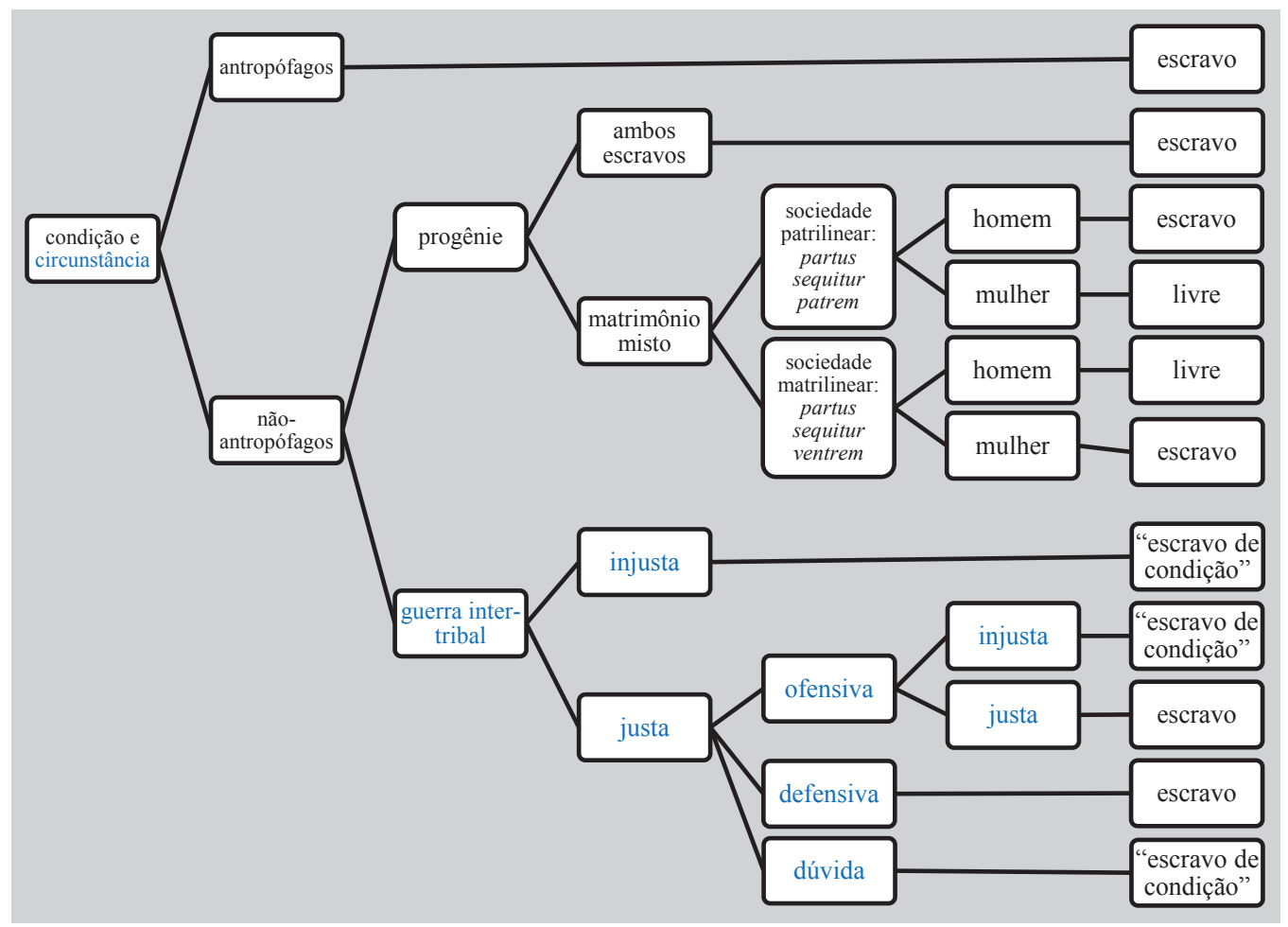

Figura 1 - Diagrama a partir das "Direções a respeito da forma que se deve ter no julgamento e liberdade no cativeiro dos índios do Maranhão” (1655).

veiro foi julgado naquele mesmo ano de 1655 não representavam mais do que uma quinta parte dos que haviam sido reduzidos à escravidão, "e contudo", diz Vieira (1951, p.56), "foram quase todos estes índios julgados por cativos". Denunciar os abusos e tiranias aos quais ele mesmo deu margem de pouco lhe serviu; tampouco foi eficaz sua estratégia de subordinar a reprodução da mão de obra escrava indígena aos interesses da Companhia de Jesus, conforme os termos das leis de 1653 e 1655 , e ainda ao pretender receber os referidos "escravos de condição", ao cabo dos cinco anos de serviço, nos aldeamentos de índios dos quais os jesuítas tinham a responsabilidade: em 1661, os jesuítas foram expulsos do Maranhão.

Vieira só voltou ao Brasil em 1681, aos 73 anos de idade, passando a residir na Quinta do Tanque, propriedade campestre da Companhia de Jesus nas proximidades de Salvador da Bahia. Ali ele preparou para publicação os quinze volumes de seus famosos sermões, os quais, contudo, ele chamou de meras "choupanas", comparados aos "palácios altíssimos" de seus textos de interpretação de profecias. Mas continuou politicamente extremamente ativo, pois ali ele enfrentou também as consequências da promulgação do alvará de 1680, de teor semelhante à lei de 1652, e do qual ele foi o principal artífice: houve grandes revoltas entre os moradores, culminando na expulsão dos jesuítas e do governador do Maranhão, e, no Brasil, em diversas ameaças de expulsão, sobretudo 
em São Paulo; tais revoltas geraram também profundas divisões no interior da província jesuítica do Brasil, opondo a "facção" dos "estrangeiros" à dos "vieiristas" (Zeron, 2015).

Para constituir a imagem de Vieira como defensor da liberdade dos ameríndios, é comum a historiografia referir-se ao texto onde Vieira enfrentou todas aquelas oposições, dos moradores e dos seus próprios correligionários: o "Voto sobre as dúvidas dos moradores de São Paulo acerca da administração dos índios”, emitido em 1694. Todavia, apesar de frases de efeito indelével sobre a soberania e a liberdade dos índios, ${ }^{2}$ uma coisa e outra são fortemente limitadas, na parte final do texto. De fato, por um lado, Vieira constata que "as famílias dos Portugueses e Índios em S. Paulo estão tão ligadas umas com as outras", apesar da condição servil e submissa dos índios, que "desunir esta tão natural ou tão naturalizada união, seria gênero de crueldade entre os que assim se criaram e há muitos anos vivem". Por outro lado, os demais indígenas deveriam ser reduzidos nos aldeamentos, onde seriam colocados sob a tutela de administradores eclesiásticos.

Assim, sua posição mais ousada e, pode-se mesmo dizer, inovadora sobre a liberdade ou escravidão dos índios encontra-se num dos "palácios altíssimos" que ainda escrevia quando morreu, a Clavis Prophetarum, onde ele trata não dos índios que viviam misturados aos moradores portugueses, mas dos chamados tapuias, "bárbaros" que, segundo ele, "ignoram que são homens".

Se eu disse que sua posição é ousada e mesmo inovadora é porque, ao tratar dos tapuias, Vieira questiona princípios fundamentais do pensamento estoico e cristão concernentes (a) à igualdade substancial entre os homens, (b) ao plano ético das relações entre os homens, baseado na lei natural, (c) e ao conhecimento natural de Deus, baseado na observação da ordem da natureza. Nesse sentido, Vieira coloca em questão inclusive o pensamento de Paulo, que tinha apontado aos pagãos o "caminho para o conhecimento natural de Deus, baseado no conhecimento da natureza e da ordem do mundo físico" (Calafate, 2013-2014, p.114). Com efeito, quando Vieira afirma que os tapuias são "homens em vão", ele opõe-se ao argumento de Paulo sobre a culpa dos pagãos; pois, para Vieira, os tapuias tinham uma "ignorância invencível" da lei natural e, no entanto, seriam salvos.

$\mathrm{Na}$ Clavis Prophetarum, Vieira escolhe como antagonistas os padres jesuítas Francisco Suárez (divergindo do De legibus, II, V, 12-13, II, VII, 5-6, II, VIII, 7-8; entre outras passagens) e, em segundo plano, Diego Granado; mas, sua divergência se estende a São Paulo (Rm. 2,14-15), Santo Ambrósio (In Psalmum XXXV enarratio n.19), Santo Agostinho (De sermone domino in monte, II, 9), Santo Tomás de Aquino (Suma teológica, I-II, q.94, a.6), entre outros, incluindo o jesuíta Luís de Molina (De iustitia et iure, I, 1, disp. 3), que em outros textos e ocasiões ele escolhera como uma fonte particularmente autorizada para tratar dos índios e da escravidão. ${ }^{3}$ 
Na Clavis Prophetarum, Vieira afirma que, a despeito da atividade dos apóstolos, o Evangelho não foi pregado no interior da África e da América, nem na Terra Austral, nem na China e muitas outras regiões da Ásia. Algumas populações dessas regiões tiveram algum conhecimento de Deus, contudo, por meio das leis naturais. Mas não os tapuias, que se encontravam numa situação de ignorância invencível com relação a ambos.

São duas opiniões contrárias, portanto: a daqueles que afirmam que a lei natural e a luz natural da razão vigoram mesmo entre os bárbaros, aos quais Vieira responde que são muitos, mas não todos; e a daqueles aos quais Vieira apelou para confirmar sua posição, que sustentam que certas populações vivem numa ignorância invencível tanto da lei natural quanto de Deus. Ao escolher esses autores, o argumento de Vieira é de que as testemunhas da realidade americana sabem mais que quaisquer filósofos pagãos ou doutores da Igreja. Assim, ele escreve num tom desafiador:

Aos restantes autores alegados, que são os dos nossos tempos e da nossa escola e defendem a mesma opinião [da impossibilidade da ignorância da lei natural e de Deus], que direi eu? Apenas isto: que estão na Europa e escrevem da Europa. Lembrem-se de que grande é a diferença com que se creem ou julgam as coisas que entram pelos ouvidos e "aquelas que são oferecidas aos olhos fieis". [...] Venham, pois, e tendo então a experiência por juiz, constará se nos querem ensinar de outro modo, ou se querem eles próprios concordar conosco. É inevitável, ó mais ilustres dos teólogos, que sintais que entre os vossos raciocínios e os nossos olhos há um grande abismo e talvez maior que o próprio oceano que se estende entre nós. (Vieira, 2000, p.399-401 $)^{4}$

Nesse sentido, Vieira qualifica suas principais fontes e testemunhas como “oráculos" (Vieira, 2000, p.349, 351 e 359); ; são eles: José de Acosta, Juan de Solórzano Pereira e o bispo de Quito, Alonso de la Peña de Montenegro.

Mas, o que dizem os "oráculos" de Vieira? Eles de fato adaptaram os conceitos teológico-jurídicos aos contextos coloniais? Que distinções fizeram sobre a lei e o direito natural, à luz da realidade americana?

Acosta, Solórzano e Alonso de la Peña trabalham com a divisão dos bárbaros em três classes; já Vieira distingue, dentre todos, os tapuias, como se constituíssem uma quarta classe.

Tapuia, segundo a Arte de Grammatica da Lingoa mais usada na Costa do Brasil, do Padre José de Anchieta, designa qualquer indígena de grupo tribal não tupi, ou índio não falante da língua tupi predominante na costa atlântica sul-americana. Por extensão, pode significar os inimigos dos tupis, que eram os principais aliados dos portugueses; ou seja, tapuias podiam ser todos os índios não submetidos do interior do continente americano, até o sopé da cordilheira dos Andes, incluindo também os que ainda resistiam aos portugueses no litoral; 
por extensão, enfim, tapuia pode significar também escravo, ou cativo, conforme o Vocabulário na língua brasílica, um manuscrito português-tupi do início do século XVII.

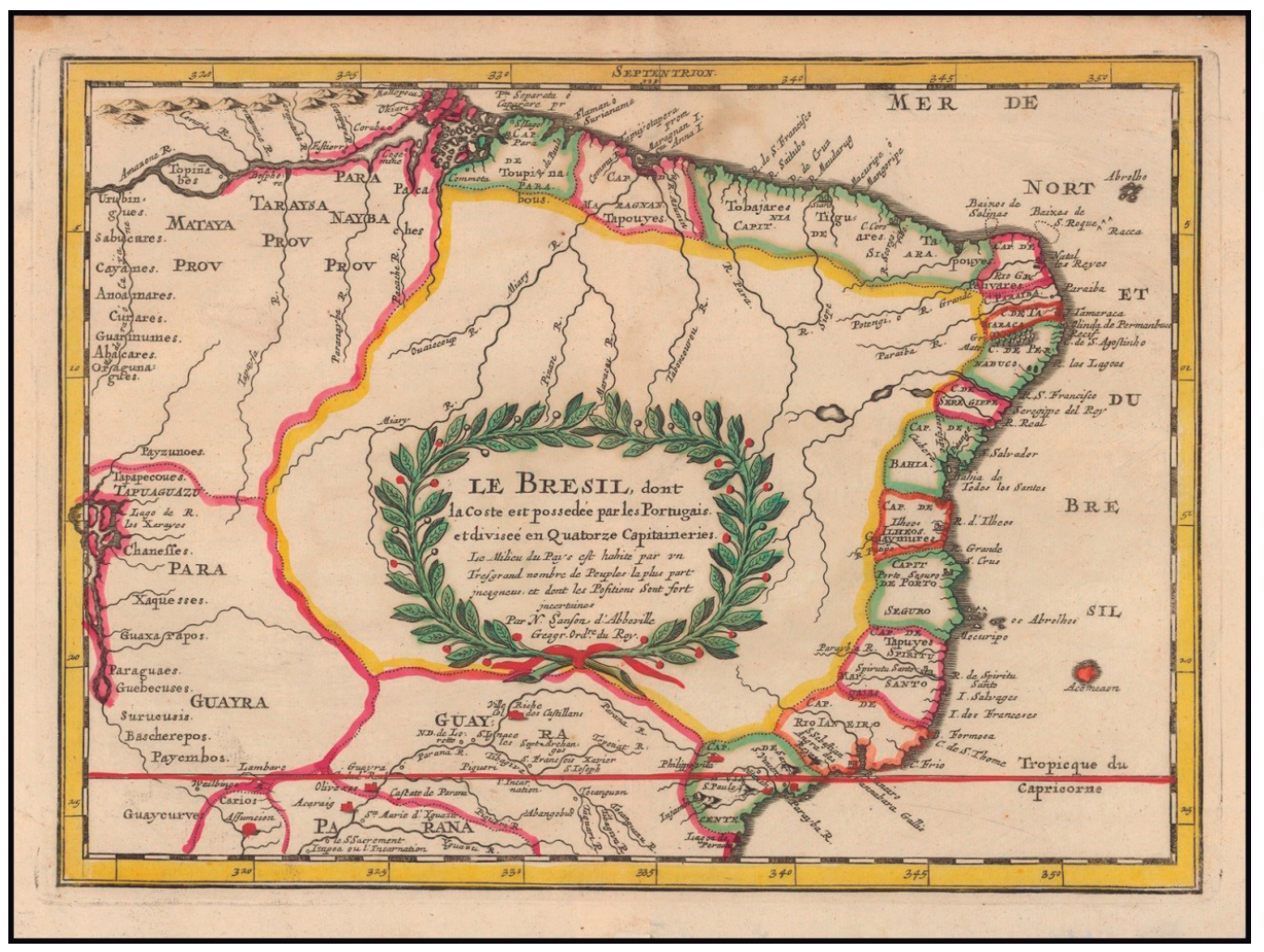

Figura 2 - Nicholas Sanson d'Abbeville. Le Bresil, dont la coste est possedée par les Portugais et divisée en quatorze capitanieries [sic]... Paris, $1657 .{ }^{6}$

Mas Vieira descreve os tapuias por meio de outras categorias, equivalentes àquelas com que Alonso de la Peña distingue os ameríndios de todos os demais povos pagãos, isto é, como "rústicos" e "miseráveis".7 Dessa maneira, Vieira, como Alonso de la Peña, recusa aplicar aos tapuias a categoria explicativa aristotélica da servidão natural, ambiguamente aceita por Acosta e, sem grandes hesitações, por Solórzano.

Sendo rústicos e miseráveis, os ameríndios descritos por Alonso de la Peña e, especificamente, os tapuias descritos por Vieira não sabem "filosofar". Para o bispo de Quito, "nisto se diferenciam de todas as Nações bárbaras do mundo"; para o jesuíta, os tapuias são "homens em vão" por não fazerem pleno uso de suas capacidades racionais, as quais se foram obscurecendo e extinguindo a ponto de não mais conseguirem distinguir o bem do mal.

Se para Solórzano o costume, entendido como uma segunda natureza, não desculpa os crimes cometidos pelos índios e justifica a sua dominação pela força - o que Acosta aceita com algumas nuances e condições - para Vieira é 
justamente o costume que desculpa os tapuias. Reiterado por gerações, Vieira (1953, p.181) concedia aos tapuias "não só uma ignorância invencível de Deus, por todo o decurso das suas vidas, mas também ignorância de todo o Direito Natural". Nesse sentido, algum ato que cometem, afirma, é "pecado puramente filosófico e não teológico", ao passo que "o pecado dos Cristãos e dos Idólatras contra a razão natural não é puramente filosófico, mas é também teológico" (ibidem); por essa razão, "se os teólogos da Europa (que negam ser possível a ignorância de Deus e do Direito Natural) praticassem com estes bárbaros, cederiam da sua opinião" (ibidem, p.201).

Quanto a esse ponto, contudo, Alonso de la Peña distancia-se ainda mais dos preceitos agostinianos, ${ }^{8}$ pois o costume explica e desculpa não apenas os índios que ainda não tinham sido convertidos, mas também os convertidos que viviam longe dos cristãos.

Segundo o jesuíta Carlo Antonio Casnedi, que resumiu e comentou a Clavis Prophetarum pouco depois da morte de Vieira, suas posições não podiam ser condenadas nem mesmo a posteriori pelo decreto papal de 1690; pois, "se bem se examinar, ver-se-á que Alexandre VIII [...] não diz conhecimento invencível" (Vieira, 1953, p.178; Colombo, 2006, p.227-8).

Assim, se Acosta, Solórzano e mesmo Alonso de la Peña buscam o que entendem ser o justo meio-termo aristotélico entre duas posições extremas, Vieira assume que os tapuias constituem uma exceção. Consequentemente, a estratégia tomista de induzir o temor filial a partir do temor servil não se lhes aplica. Isto é, em Vieira mais do que nos outros autores aos quais ele se reporta e cuja autoridade busca em apoio às suas teses, a consideração das circunstâncias históricas e as ponderações de ordem geopolítica adquirem maior peso. Minha hipótese para explicar essa postura é que Vieira tem no horizonte a construção do Quinto Império, o qual no seu entender será português. O Brasil ocupava um lugar estratégico nesse plano, porque a conversão universal do gênero humano deveria começar por ali, e era necessário, portanto, manter a posse do território.

Solórzano é o outro autor, dos quatro aqui considerados, que tem uma forte perspectiva imperial, mas ele a resolve de outra maneira: não ponderando as dificuldades de subjugar as nações resistentes, como faz Vieira, mas simplesmente autorizando e legitimando o uso da força contra elas.

Para Solórzano, os pecados contra a lei natural (reunidos na noção de barbárie) justificam a guerra justa e a perda de domínio; além disso, ele acrescenta os princípios postos anteriormente por Francisco de Vitoria, concernentes ao direito natural de comércio, de trânsito, de hospitalidade, de defesa dos inocentes e mesmo do tiranicídio. Ao passo que Vieira recusa explicitamente o motivo de pecados contra a lei natural, aproximando-se, nesse ponto, de Alonso de la Peña, que desculpa os índios seja por inadvertência, seja por ignorância, qualificada como invencível, seja devido à sua posição geográfica (a distância da sociedade colonial, quando dela se afastam e, mesmo convertidos, voltam aos 
seus usos ancestrais), seja, enfim, por causa da sua rusticidade e da reiteração de erros pelo costume.

Assim, a defesa dos inocentes, que desde Vitoria até Acosta e Solórzano era um motivo justo para invadir, depor e dominar, não constitui um tema de discussão em Alonso de la Peña, nem em Vieira.

Tudo considerado, a estratégia da adequação e da acomodação encontra-se presente em todos os quatro autores, mas adquire um peso maior em Alonso de la Peña, devido ao imperativo da rusticidade e miserabilidade dos índios, e mais ainda em Vieira, devido à impossibilidade de sequer missionar entre os tapuias, seja pacificamente, seja com apoio militar, simulacro da ira divina. ${ }^{9}$ Nesse sentido, Vieira salienta que a África e o Brasil não podem ser comparados ao México e ao Peru.

A essa altura, considerando os argumentos e as posições de Vieira na Clavis prophetarum, singulares inclusive com relação aos autores que ele cita para sustentar as suas teses, é importante aprofundar qual era a experiência do jesuíta com os tapuias e com os africanos. A esse tema dedico as duas seções seguintes.

O contato direto de Vieira com os índios tapuias, especialmente das nações dos aroãs, curutis e tobajaras, ${ }^{10}$ acontece principalmente na missão da Serra de Ibiapaba, no Maranhão, sobre a qual o jesuíta escreveu uma longa relação, em 1660 (Vieira, 1951, p.72-134).

O topônimo Ibiapaba deriva do termo tupi yby'ababa, que significa "terra talhada", "terra fendida" (Navarro, 2013, p.565; Vieira, 1951, p.96). O nome procede das suas características: um aclive suave e gradual em direção ao leste subitamente interrompido por uma escarpa abrupta e muito íngreme, com alturas médias de 750 a 900 metros e longa de cerca de $200 \mathrm{~km}$, de norte a sul. ${ }^{11}$

A imagem de uma terra fendida, talhada, ajusta-se não apenas ao seu aspecto físico, mas também às dificuldades de ligação entre o estado do Maranhão e Grão-Pará e o estado do Brasil. De fato, era inviável navegar do Maranhão para o Brasil devido aos ventos alísios de nordeste e às correntes sul-equatorial e das Guianas. Conforme o depoimento de Vieira:

Uma das mais dificultosas e trabalhosas navegações de todo o Mar Oceano é a que se faz do Maranhão até o Ceará por costa, não só pelos muitos e cegos baixios, de que toda está cortada, mas muito mais pela pertinácia dos ventos e perpétua correnteza das águas. Vem esta correnteza feita desde o cabo da Boa Esperança com todo o peso das águas do Oceano [...] de sorte que do Pará para o Maranhão de nenhum modo se pode navegar por fora, e do Maranhão para o Ceará com grandíssima dificuldade, e só em certos meses do ano, que são os de maior inverno. (Vieira, 1951, p.86-7)

Tentando vencer esse trecho do Maranhão para o Ceará (onde se situa a Serra de Ibiapaba), Vieira relata que dois missionários gastaram cinquenta dias para avançar num trajeto que foi desfeito em apenas doze horas, por ventos e correntes (Vieira, 1951, p.87). ${ }^{12}$ 
O caminho alternativo seria por terra. Mas entre o estado do Maranhão e Grão-Pará e o estado do Brasil, ${ }^{13}$ entre a Missão do Maranhão e a Província jesuítica do Brasil, encontravam-se os tapuias, inclusive e particularmente na região da Serra de Ibiapaba. E, o que tornava a situação ainda mais complexa, alguns desses tapuias já teriam sido aliados dos holandeses contra os portugueses, quando os batavos ocuparam as capitanias do nordeste da América portuguesa. ${ }^{14}$ Após a sua expulsão, vários grupos tapuias teriam migrado em direção àquela serra, de modo que, segundo Vieira, "ficou Ibiapaba verdadeiramente a Genebra de todos os sertões do Brasil, porque muitos dos índios pernambucanos foram nascidos e criados entre os Holandeses", ficando "tão calvinistas e luteranos, como se nasceram em Inglaterra ou Alemanha" (Vieira, 1951, p.81 e 114 , respectivamente).

Nesse sentido, a imagem e o topônimo de uma "terra talhada, fendida" ajustam-se não apenas à geografia física, mas também à geopolítica: as missões que Vieira enviou à Serra de Ibiapaba, quando era superior da Missão do Maranhão, bem como a sua própria presença na região explicam-se pela sua estratégia de reunir os dois territórios, com vistas a superar não apenas os obstáculos geográficos, mas também geopolíticos. Para Vieira (1951, p.75), "ter pacificadas e quietas as nações bárbaras de tapuias, que cercavam e infestavam os arredores da serra" constituía uma estratégia fundamental para viabilizar e consolidar a construção de um império português na América.

Baseada em fontes jesuítas e em testemunhos dos próprios índios e de Vieira, a "Relação da Serra de Ibiapaba" é uma cronografia que se assenta numa concepção providencialista da história, na qual o livre-arbítrio de padres e índios colabora para a salvação de todos no âmbito do império português unificado. Nesse sentido, o trabalho dos missionários na região não é apenas de catequese, mas também de esclarecimento e convencimento político.

A relação inicia-se com uma série de oposições entre os jesuítas, de um lado, e, de outro lado, os portugueses (qualificados como torpes, cobiçosos e violentos), os franceses (que haviam ocupado o Maranhão entre 1612 e 1614), os holandeses e os índios. Em seguida, aponta quais os instrumentos privilegiados para realizar a junção entre o Maranhão e o Brasil, aproximando portugueses e índios do projeto imperial português, e combatendo os estrangeiros: para além da pregação dos missionários jesuítas, cartas de "perdão e esquecimento geral" para os índios tapuias de Ibiapaba (a fim de reverter a compra das suas "vontades e sujeição" pelos holandeses) e, complementarmente, a lei sobre o resgate de índios de 1655 (contra a "cobiça" dos portugueses). Cartas de perdão e lei sobre o resgate de índios são instrumentos que têm fundamento em "razões de Estado" (Vieira, 1951, p.89) explicitadas por Vieira, as quais requerem, para ser efetivas quanto ao seu fim, uma aliança entre a Companhia de Jesus e a coroa portuguesa. 


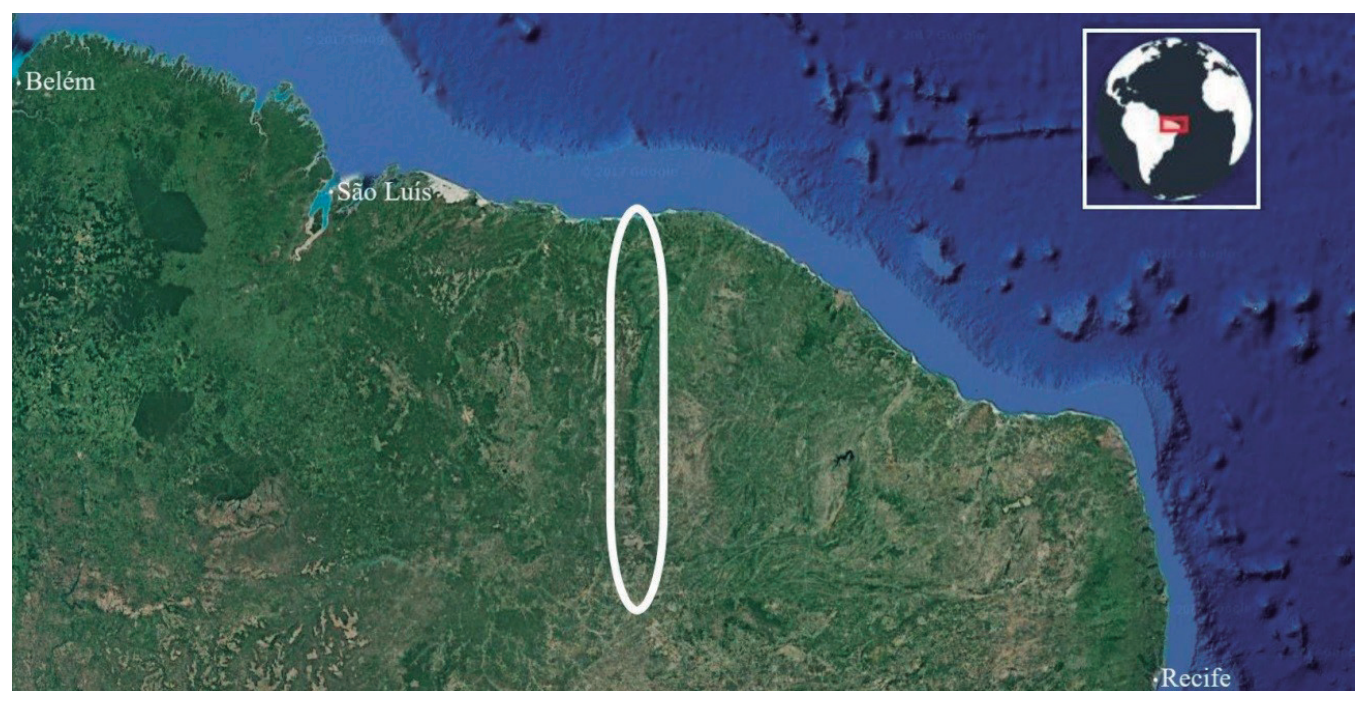

Fonte: Google maps.

Figura 3 - Serra de Ibiapaba.

Mais adiante, Vieira relata as missões realizadas em Ibiapaba, durante as quais se estabelece um jogo de tensões entre os jesuítas (que se aproximam dos índios e a eles se acomodam), os índios (que temem que os jesuítas sejam a ponta de lança dos interesses lusitanos) e os portugueses (que, movidos por cobiça, torpeza e luxúria, dão aos índios motivos legítimos para mover-lhes uma guerra justa defensiva).

Na última parte do texto, Vieira relata como teve que se empenhar pessoalmente, afinal, para viabilizar a missão entre tais nações. A mudança naquela conjuntura hostil ocorre, segundo Vieira (1951, p.120-3), depois de alguns sinais divinos manifestados aos índios sob a forma de visões, sonhos e exorcismos, ${ }^{15}$ os quais acabam induzindo os índios de Ibiapaba a aderirem à proposta do jesuíta, qual seja: “os índios da rebelião de Pernambuco, que ali estavam retirados" (ibidem, p.275) deveriam migrar para o Maranhão, inclusive "obrigados a isso por força", separando-se assim dos índios que poderiam permanecer na região de Ibiapaba sob a tutela espiritual e temporal dos missionários, em aldeamentos (ibidem, p.133-4).

Se confrontarmos a "Relação da Missão de Ibiapaba" com o citado "Voto sobre as dúvidas dos moradores de São Paulo", perceberemos que a distinção que Vieira fez entre tupis e tapuias se especifica e se desdobra diferentemente, conforme o contexto: em São Paulo, os tupis que já se encontravam estreitamente ligados aos portugueses poderiam permanecer em suas residências e a seu serviço, ao passo que os demais deveriam reduzir-se em aldeamentos sob a tutela de religiosos; no Maranhão, os tapuias que haviam se tornado os "maiores dogmatistas" da religião protestante deveriam ser entregues aos portugueses, inclusive "por força", ao passo que os demais deveriam reduzir-se igualmente em aldeamentos sob a tutela de jesuítas. 
Por outro lado, cabe ressaltar a estreita afinidade entre a "Relação da missão Serra de Ibiapaba" e o coetâneo "Sermão da Sexagésima", pregado na Capela Real no ano de 1655. Em ambos se encontram os temas do "missionário obreiro", do "desengano" (de índios e de portugueses) e da "unidade na diversidade", convergindo na definição do "sentido verdadeiro" da missão, por meio da qual a tribuna de Deus impõe-se sobre a tribuna dos reis. Essa ordem induz a uma aliança da coroa com a Companhia de Jesus, contra os portugueses maus-cristãos, no "Sermão da Sexagésima", e ainda contra os holandeses e os tapuias tobajaras, na "Relação da Serra de Ibiapaba".

Contra os holandeses, a guerra, ${ }^{16}$ contra os "maus-cristãos" e os índios inimigos, a aliança que se manifesta e viabiliza por meio daquilo que, no "Sermão da Sexagésima", Vieira chama de "instrumentos": a pregação eficiente, que "desengana" porque feita de "palavras e obras", mas também as leis positivas civis que regram o comportamento dos homens, fossem eles colonos ou índios - visto que, por motivos diferentes (cobiça, costumes etc.), uns e outros eram incapazes de realizar adequadamente a sindérese.

Assim, após ter analisado as dificuldades da conjuntura do Maranhão, foi uma lei que Vieira quis buscar em Portugal, em 1655. A lei "Sobre os índios do Maranhão" (Lei..., 1948, p.25-8) que ele obteve naquele mesmo ano permitia à Companhia de Jesus tutelar soberanamente a sociedade colonial, colocando-a acima dos índios e dos "maus-cristãos" portugueses na medida em que entregava aos jesuítas a supervisão de todas as expedições de descimento de índios, bem como a gestão exclusiva dos aldeamentos. Nesses espaços eram reunidos índios de diversas etnias, os quais constituíam a principal reserva de mão de obra da colônia e exército de defesa das conquistas portuguesas. A lei tinha como contrapartida várias formas de submissão e dependência dos índios: a escravidão (inclusive aquela temporária, chamada "de condição"), o trabalho compulsório dos índios ditos "livres", a mestiçagem cultural e biológica com os colonos e a tutela dos aldeados pelos padres jesuítas. Mas para aqueles tapuias da Serra de Ibiapaba que poderiam continuar residindo na região, Vieira requereu "cartas de perdão" que lhes davam autonomia política, longe dos portugueses, restringida apenas pela presença tutelar dos jesuítas.

A centralidade do Sermão da Sexagésima na obra de Vieira fica assim bastante clara: não apenas por causa das diretrizes retóricas que ele ali prescreve (pelo qual é mais conhecido), mas, igualmente, por causa da importância que ele atribui aos chamados "instrumentos" na atuação dos missionários; instrumentos que longe de se limitarem à pregação, compreendem também todas as formas de colaboração e concórdia entre as duas espadas.

Atendido em sua demanda por um monarca que sempre o escutou e seguiu nas questões de política indigenista, a lei de 1655 colocou a Companhia de Jesus no centro do dispositivo econômico, político e militar do Maranhão - em linha com o privilégio que o primeiro provincial do Brasil, Manuel da Nóbrega, 
já tinha obtido em meados do século XVI para os jesuítas daquela Província (Zeron, 2011).

Mas enquanto Nóbrega condiciona a obtenção de “grossos rendimentos nessas terras” à sujeição dos índios indomáveis (Leite, 1938-1950, IV, p.447-8), Vieira (2000, p.465-7) afirma que "Deus providenciou não providenciando":

Previu, pois, o providentíssimo Senhor que os gentios que ignoram Deus invencivelmente, se lhes proporcionasse um ou outro meio, ou ambos, necessários para o conhecimento de Deus, todos ou a maior parte deles haviam de cometer, com a própria fé, muitos pecados mortais, e por isso deveriam ser condenados às penas eternas do Inferno. Pelo contrário, desprovidos desses meios, na ignorância de Deus, em que nasceram e foram criados, viveriam, envelheceriam e morreriam, havendo de ser isentos de metade, ao menos, daquelas penas, isto é, da pena eterna dos sentidos. Por que razão misericordiosamente o fez? Desistiu ou absteve-se de lhes conceder a perspicácia do intelecto e a pregação do Evangelho, e, negando estes dois benefícios, com um novo gênero de misericórdia, desta sorte providencia não providenciando. ${ }^{17}$

Esse "novo tipo de misericordia" aplicar-se-ia, em princípio, a todos os tapuias que vivessem em situação de "ignorância invencível".

A situação desses gentios poderia ser equiparada, então, à dos negros africanos para quem o Evangelho também não fora pregado? A resposta de Vieira, como no caso dos tapuias, é circunstanciada e objetivada em razão da construção do Império português: Deus não provê aos negros não provendo, pois eles se salvam no Brasil.

Partindo de Lisboa pela primeira vez em direção ao Maranhão, em 1652, Vieira viu-se obrigado a realizar uma escala acidental no arquipélago do Cabo Verde. Apesar da curta estada, de apenas quatro dias, ele entusiasmou-se com o que viu e passou a advogar ${ }^{18}$ a reativação da missão do Cabo Verde e da "costa que lhe corresponde em Guiné".

De fato, na primeira carta que de lá escreveu encontra-se o seguinte comentário: "Há aqui clérigos e cônegos tão negros como azeviche, mas tão compostos, tão autorizados, tão devotos, tão grandes músicos, tão discretos e bem morigerados, que podem fazer invejas aos que lá [em Portugal] vemos nas nossas catedrais" (Vieira, 1928, v.I, p.295). O pronunciamento contrasta com outros em que empregou a noção aristotélica de "servidão natural" para qualificar os negros africanos. Por exemplo, na resposta ao procurador do Maranhão, Jorge de Sampaio, em 1662: “[...] é gente por sua natureza serviçal, dura e capaz de todo o trabalho, e que o atura e vive por muitos anos, se a fome e o mau tratamento os não acaba" (Vieira, 1951, p.298-9). ${ }^{19}$

A explicação para assertivas tão contrastantes encontra-se nas circunstâncias em que foram feitas, a meu ver, estreitamente relacionadas à solução que ele vai elaborando, por um lado, para o problema da pressão que a colonização 
portuguesa exercia sobre os ameríndios e, por outro, para viabilizar a unificação do Império português na América, reunindo Brasil e Maranhão por meio do sertão nordestino.

Em uma economia escravista como a do Brasil colonial, Vieira entendia que a liberdade ou mesmo, apenas, a sobrevivência dos índios só poderia ser garantida substituindo seu trabalho por aquele de origem africana - o que ele propôs em diversas ocasiões, inclusive no Maranhão. Complementarmente, era necessário induzir os africanos a aceitar a escravidão - no que ele esmerou-se, em seus sermões, procurando convencê-los que a resignação e a obediência favoreceriam a salvação de suas almas.

Vieira pronunciou-se poucas vezes a respeito da escravidão dos africanos, fazendo-o de maneira mais detida apenas nos três sermões dirigidos aos negros da confraria de Nossa Senhora do Rosário.

A análise desses sermões deve sopesar duas circunstâncias, simultaneamente: a situação de enunciação e a revisão para publicação, quando eles passaram por um processo de reescrita, antes de serem publicados em dois volumes, em 1686 e 1688. O sermão XIV, alegadamente, teria sido pregado num engenho da Bahia para a Irmandade dos Negros do Rosário, em 1633, no dia da festa da santa protetora. Não temos nenhuma informação sobre as circunstâncias que envolveram a pregação do sermão XX, a não ser que ele remete à mesma festa. ${ }^{20}$ O sermão XXVII, enfim, referir-se-ia a uma prédica realizada sempre na mesma festa, na Bahia, mas em 1680. Já a circunstância de revisão dos sermões para publicação aparece marcada principalmente pelos diversos motins que se sucederam à promulgação da lei de 1680 (que, por sugestão do próprio Vieira, declarava a liberdade dos índios sem a restrição usual dos títulos da guerra justa e do resgate) e pelo fracasso dos ataques contra o quilombo dos Palmares, situado no sertão nordestino, não muito distante de Recife e a mil quilômetros da Serra de Ibiapaba, o qual foi subjugado somente na virada do século XVII para o XVIII.

Muitos estudos já foram feitos sobre a retórica dos sermões de Vieira e a maneira como ele recorreu tanto à afetividade do ouvinte/leitor como à sua instrução teológica. Um de seus principais estudiosos, Alcir Pécora (2005, p.30), propôs um método analítico que estabelece uma analogia entre três linhas semânticas presentes nos sermões, relacionadas às comemorações do ano eclesiástico ou litúrgico (isto é, o tempo santo), às passagens do Evangelho determinadas pelo calendário litúrgico e, enfim, às circunstâncias do tempo histórico (que, segundo a ortodoxia católica, não estaria em contradição com o tempo santo). Mas o que entenderiam os "rudes africanos" de toda essa "pomposa retórica"? - perguntou-se João Lúcio de Azevedo (1992, II, p.245, 246), a propósito dos sermões do Rosário. Ele próprio respondeu que pouco importava, pois "o fim do orador era incutir-lhes a conformidade".

É de fato a impressão que se tem da leitura daqueles três sermões. No sermão XIV, por exemplo, lê-se: "este que pode parecer desterro, cativeiro e 
desgraça, e não é senão milagre, e grande milagre!" (Vieira, 1945-1948, v.XI, p.305). E desde a primeira parte do sermão XXVII, o jesuíta equipara o tráfico negreiro à "transmigração da Babilônia": Ainda que o comércio de escravos fosse um "trato desumano" e uma "mercancia diabólica", o tráfico negreiro guardava em si um "sentido místico" e um "mistério": Deus provia à deportação dos africanos em direção ao Brasil como condição para a salvação de suas almas, após a morte. Vieira explica o que fazia do tráfico um "mistério" e uma "graça", adentrando a seção mais claramente ideológica do texto: seu argumento era que a redução à escravidão livrara os negros da situação de pecado em que viviam na África. ${ }^{21}$

Segundo Vieira, a escravidão constituía-se na oportunidade que lhes era dada de alcançarem a salvação pela devoção aos ensinamentos de Cristo durante a execução de suas tarefas laborais cotidianas, nos engenhos do Brasil. Todavia, a redenção da alma do negro não dependia propriamente da condição de servidão em que se encontravam, mas, mais do que isso, da sua obediência aos preceitos cristãos. Pois, sempre conforme a diferenciação estoica, paulina e agostiniana, a escravidão do corpo não implica a da alma. Vieira cita São Paulo, a esse respeito, nos sermões XIV e XXVII, mas a distinção fica mais clara quando cita Sêneca, no sermão XXVII: "a melhor parte do homem, que é a alma, é isenta de todo o domínio alheio, e não pode ser cativa. O corpo, e somente o corpo, sim"; "todas estas razões de Sêneca se reduzem a uma, que é serem também homens os que são escravos. Se a fortuna os fez escravos, a natureza fê-los homens". Disso ele conclui que, "se buscarmos o princípio fundamental porque Cristo sendo Redentor do gênero humano só veio remir e libertar os homens do cativeiro das almas, e não da servidão dos corpos, o fundamento claro e manifesto é porque para libertar do cativeiro dos homens bastavam homens" (Vieira, 1945-1948, v.XII, p.347).

Assim, aceitando essa condição, os escravos chegavam a suplantar a vocação dos religiosos: superavam-nos no hábito, na pobreza, na obediência, na abstinência, na vigília, na regra, na humildade e na graça (Vieira, 1945-1948, v.XI, p.360-1). Por isso, no sermão XIV aparece que a maior semelhança dos escravos era com Cristo:

Bem-aventurados vós, se soubéreis conhecer a fortuna do vosso estado, e, com a conformidade e imitação de tão alta e divina semelhança, aproveitar e santificar o trabalho! Em um engenho sois imitadores de Cristo crucificado $[\ldots]$, porque padeceis em um modo muito semelhante o que o mesmo Senhor padeceu na sua cruz e em toda a sua paixão [...] imitação que, se for acompanhada de paciência, também terá merecimento de martírio. (Vieira, 1945-1948, v.XI, p.309-10)

A aceitação da escravidão do corpo encaminhava a salvação da alma do negro que, espelhando-se em Jesus Cristo, martirizava-se em punições. Dessa forma, Vieira concedia tacitamente que os cativeiros dos africanos eram justos, assim como as punições que recebiam, por ele mesmo qualificadas de martírios. 
Somente os castigos imoderados e as vituperações do nome, cor e fortuna lhe pareciam injustos. No entanto, nem mesmo esses o moviam a desculpar as revoltas dos escravos: a salvação dos negros era possível tão somente dentro do Império português, o que supunha a sua obediência, na condição de escravos.

Tal pressuposto - histórico - manifesta-se com força e evidência numa carta escrita no ano 1691, sobre o quilombo de Palmares. Aqui já não há qualquer elaboração teológica, mas apenas a análise realista das circunstâncias: após ponderar se os negros aquilombados poderiam viver livres como os tapuias da região, afasta tal alternativa com base em uma ponderação estritamente política:

Só um meio havia eficaz e efetivo para verdadeiramente se reduzirem, que era concedendo-lhe S.M. e todos seus senhores espontânea, liberal e segura liberdade, vivendo naqueles sítios como os outros índios e gentios livres, e que então os padres fossem seus párocos e os doutrinassem como aos demais. Porém, esta mesma liberdade assim considerada seria a total destruição do Brasil, porque conhecendo os demais negros que por este meio tinham conseguido o ficar livres, cada cidade, cada vila, cada lugar, cada engenho, seriam logo outros tantos Palmares, fugindo e passando-se aos matos com todo o seu cabedal, que não é outro mais que o próprio corpo. (Vieira, 1928, v.III, p.620-1) 22

A postura de Vieira com relação às revoltas dos escravos não pode ser reduzida a mero artifício ideológico a serviço dos senhores de escravos, contudo. Por um lado, é de notar que em certas passagens de seus sermões Vieira ameaça girar a roda da fortuna, bramindo não só contra os escravos rebeldes, como também contra os senhores luxuriosos, soberbos e cobiçosos. Assim, que tivessem sido proclamados ou apenas impressos, os sermões de Vieira não se dirigiam apenas aos "rudes africanos", mas também aos senhores rudes. Por outro lado, da obediência do negro dependia não apenas a sua salvação, mas também o equilíbrio da sociedade colonial e, em última instância, a conservação do império português.

A tópica estoico-cristã que pretende que a escravidão do corpo não implica a escravidão da alma como que se desdobra, na obra de Vieira: “o Brasil tem o corpo na América e a alma na África”, ele escreveu (apud Azevedo, 1992, I, p.351) pensando naquele Brasil que se estendia de Pernambuco ao Rio de Janeiro; mas são dois corpos: o dos sermões é um corpo martirizado como o de Cristo; o da carta a Roque Monteiro Paim é rebelde e indômito. Da mesma maneira, são duas almas: a dos sermões exprime o desejo de Vieira, ao mesmo tempo político e religioso, da submissão e da conversão do negro; já a carta refere uma alma africana e livre que, assim permanecendo, seria a destruição do Brasil. Para Vieira, os dois corpos e as duas almas deviam ser reduzidos e tornados uns, conformes ao que expôs nos sermões. É de acordo com essa lógica que, na primeira metade da década de 80, Vieira redigiu os sermões aos negros da confraria de Nossa Senhora do Rosário. 
Em suma, Deus provê tanto aos negros que vivem como escravos no Brasil como aos tapuias que vivem livres e ignorantes nas suas terras. A análise sistêmica da conjuntura sul-atlântica do Império português por Vieira levou-o a propor à coroa substituir ou complementar a mão de obra indígena pela negra, ${ }^{23}$ exigir a obediência dos escravos negros e especificamente a submissão do Quilombo de Palmares, fazer concessões a moradores portugueses nas regiões limítrofes das conquistas portuguesas (São Paulo e Maranhão, cf. Vieira, 1951, p.28-32 e 340-58), e negociar um pacto com os tapuias de Ibiapaba. O pregador entendia que essas propostas eram convergentes para a construção do Império, no sentido providencial que ele atribuía ao Estado português; um império universal que, conforme ele sugere na carta ao Padre Iquazafigo (Vieira, 1928, v.III, p.772), começava pela conversão da gentilidade ameríndia e africana no Brasil, sob os auspícios da coroa bragantina.

Se Vieira não justifica os negros africanos, leva ao limite a inocência dos índios tapuias que ainda resistiam e delimitavam os confins do império português. Tal distinção baseia-se na sua observação e na sua experiência: "inclinados são ao engano os elegantes raciocínios feitos de longe, com que julgamos os outros por nós próprios, quando primeiro deveríamos conhecê-los para depois os avaliar por eles próprios" (Vieira, 2000, p.385). O enunciado relativista de Vieira nada possui de anacrônico; à maneira das considerações de Michel de Montaigne sobre os "canibais" (Ensaios, I, 31), o que ele de fato pretende é acusar os teólogos e juristas europeus; no seu caso, trata-se de apontar a negligência desses em buscar a "conveniência" entre as dimensões temporais e espirituais do império português (cf. Puente, 1612). Para Vieira, é a casuística, embasada na lei natural e nos princípios da analogia, prudência e equidade que revela essa conveniência. Assim ele retoma, interpreta e atualiza Tomás de Aquino.

De fato, para o autor da Suma teólógica, a lei natural não contém detalhes ou preceitos particulares, nem se expressa numa tábua de leis; é apenas um quadro geral a partir do qual se fazem escolhas particulares em circunstâncias particulares. Por isso ela precisa ser complementada pela razão prática e pela lei humana (I-II, q.91, a.3 e q.90, a.4). Os homens podem, portanto, participar nessa determinação (I-II, q.91, a.2). De que maneira? Com base em que na lei natural há uma distinção entre os preceitos primeiros (buscar o bem e evitar o $\mathrm{mal}^{24}$ ) e os preceitos segundos, sendo que estes últimos variam em função das circunstâncias, mas também dos costumes e dos hábitos (I-II, q.94, a.6). Já o direito natural é multiforme, porque é uma relação entre pessoas e coisas. O papel do intelecto humano nos preceitos segundos é, então, o de empreender uma decodificação. Nesse sentido Tomás de Aquino afirma a mutabilidade do direito natural. Contudo, também a lei natural pode mudar, ainda que não por subtração, mas apenas por adições; por exemplo, instituindo a escravidão e a propriedade, em razão do bem comum. A lei natural e o direito natural podem 
mudar circunstancialmente, portanto, em razão do livre arbítrio dos homens, do exercício da prudência e da equidade (epikeia), desde que não contradigam a lei divina, nem os preceitos gerais da lei natural (I-II, q.96, a.6 e q.97, a.4). Assim, quando Vieira analisa a situação dos tapuias - sua classificação sui generis entre as nações; sua ignorância invencível tanto de Deus quanto da lei natural - é com base nas alterações possíveis da lei e do direito natural que ele estabelece o modo de julgar e incorporar aquelas tribos à monarquia, com vistas à sua unidade, universalidade e santidade, dentro do plano salvífico que ele anuncia como o advento do Quinto Império, expressão da conveniência entre o Império português e o divino.

Vieira retoma pontual e circunstanciadamente aquelas premissas escolásticas postas por Tomás de Aquino, o que o autoriza e permite romper não apenas com uma tradição cristã (Paulo, Ambrósio, Agostinho e, até certo ponto, o próprio Tomás de Aquino, conforme apontei acima), mas, sobretudo, com as posições assumidas por teólogos, juristas e missionários a ele contemporâneos; pois, para Vieira, algumas populações viviam numa ignorância invencível tanto da lei natural quanto de Deus, e mesmo assim seriam salvas. Ao passo que muitos de seus correligionários aderiam à ordem “compelle eos intrare” (Zeron, 2018) e ao seu corolário mais ordinário, a redução à escravidão, Vieira distinguiu a situação dos tapuias da dos tupis e dos negros africanos, com vistas à eficácia histórica do advento do Quinto Império.

\section{Notas}

l O autor agradece ao $\mathrm{CNPq}$ a bolsa de produtividade em pesquisa que permitiu a realização deste trabalho. Uma versão preliminar foi publicada em Zeron et al. (2018, p.139-65).

2 “[...] não são escravos, nem ainda vassalos. Escravos não, porque não são tomados em guerra justa; e vassalos também não, porque assim como o espanhol ou o genovês cativo em Argel é contudo vassalo do seu rei e da sua república, assim o não deixa de ser o índio, posto que forçado e cativo, como membro que é do corpo e cabeça política da sua nação, importando igualmente para a soberania da liberdade, tanto a coroa de penas, como a de ouro, e tanto o arco como o cetro" (Vieira, 1951, p.341-2).

3 Por exemplo, na "Informação sobre o modo com que foram tomados e sentenciados por cativos os índios do ano de 1655" (Vieira, 1951, p.60-1).

4 A frase “quae sunt oculis subjecta fidelis" encontra-se em Quinto Horácio Flaco, Arte poética, $\mathrm{V}, 181$.

5 Em segundo plano, Vieira cita Pedro Mártir d'Anghiera e Tomás Bózio, qualificados como "insignes nas letras, na religião e na autoridade pública" (Vieira, 2000, p.367).

6 Além das capitanias de Maranhão, Ceará e Espírito Santo, onde se localizam os índios tapuias, a versão precedente desse mapa, datada de 1656, localiza e discrimina outros povos no interior do Brasil que, entretanto, eram comumente conhecidos apenas como tapuias, por oposição aos tupis da costa. Conforme comentam Wright e Cunha (1996-2000, p.335), "In contrast to the relatively homogeneous Tupi and Guarani cul- 
tures of the coast, those of the vast regions of the northeastern interior presented to the early Portuguese chroniclers an enormous and bewildering diversity. This contrast formed the basis for the fundamental dichotomy between the Tupi and 'Tapuya' (Tapuia in Spanish context) - a generic designation for 'enemy others' originally used by the Tupi to refer to all peoples of the interior - that shaped conceptions about the Indians of Brazil and most specially the northeast throughout the colonial period" (ver também ibidem, p.297). De fato, Vieira escreve "Tapuias Aroãs" e "Tapuias Curutis" na "Relação da missão da Serra de Ibiapaba", que comentarei adiante, ou generaliza "Tapuias do mato", na "Resposta aos capítulos que deu contra os religiosos da Companhia, em 1662, o procurador do Maranhão Jorge de Sampaio" (Vieira, 1951, p.76, 119, 281 e 282). Já uma versão oitocentista desse mesmo mapa de Sanson d'Abbeville designa uniformemente o interior do Brasil como território tapuia.

7 No que se aproximam da condição jurídica dos menores, dos órfãos, das viúvas e dos enfermos.

8 Santo Agostinho constata a diversidade das crenças e costumes, que ele só tolera “contanto que tais usanças não sejam empeço àquela religião que ensina a adorar um Deus único, verdadeiro e soberano" (Cidade de Deus, XIX, 17).

$9 \mathrm{Na}$ "Relação da Missão de Ibiapaba” (1656), Vieira, equiparando-se a Francisco Xavier, mostra como teve que empenhar-se pessoalmente para tentar viabilizar uma missão entre tais nações.

10 Segundo Vieira (1951, p.84), todo o caminho em direção à Serra de Ibiapaba estava "infestado de diversas nações de Tapuias", enquanto nas montanhas ele enfrentou principalmente a hostilidade dos grupo Tobajaras. De fato, no Maranhão e Grão-Pará, Vieira distinguia “as nações dos Tupinambás, Poquiguaras, Catingas, Bocas, Mapuás, Anajás, Mamaianas, Aroans, Paricis, Tapajós, Murucucus, Mariás, Juruúnas, Nonhunas, e os Pocujus, Aroaquis e outros" (ibidem, p.155-6).

11 "O processo erosivo cenozóico, diferencial, rebaixou parcela dos terrenos cristalinos, os mais frágeis, deixando em ressalto as rochas sedimentares e as litologias cristalinas mais resistentes, criando um desnível da ordem de $900 \mathrm{~m}$, o qual corresponde à vertente do Glint da Ibiapaba e ao topo dos maciços cristalinos." (Claudino-Sales; Lira, 2011, p.207).

12 O próprio Vieira (1951, p.88) desistiu de ir à Bahia buscar mais missionários.

13 A Missão do Maranhão ora subordinou-se à Província do Brasil, ora à Província de Portugal, neste último caso por imperativos geográficos relacionados à maior facilidade de comunicação que não impediram, contudo, a eclosão fortes querelas interprovinciais (Leite, 1938-1950, p.213-22).

14 “[...] os Holandeses ocuparam Pernambuco e pouco depois se fizeram senhores da fortaleza do Ceará e reduziram a si todos os índios daquela vizinhança” (Vieira, 1951, p.77).

15 Vieira também invoca São Francisco Xavier, por meio de uma imagem que para lá havia sido levada, esperando que “assim como Deus tem feito este grande apóstolo tão milagroso na Europa, na África e na Ásia, se estenderão também os favores da sua valia e intercessão a esta parte da América” (Vieira, 1951, p.133), preparando assim a conversão universal do gênero humano no advento do Quinto Império. 
16 Nesse sentido, ver o primeiro texto conhecido de Vieira, onde os religiosos têm um papael predominante na guerra contra os holandeses que haviam ocupado a Bahia, em 1624: além dos jesuítas que apoiavam os combatentes portugueses, Vieira ressalta o empenho do bispo, quem "determinou trocar o bago com a lança, e o roquete com a saia de malha, e de prelado eclesiástico fazer-se capitão de soldados" (Vieira, 1928, I, p.25). A sua narrativa está de acordo com a posição de Tomás de Aquino, Summae Theologiae, II-II, q. 40, a. 2, "Utrum clericis et episcopis sit licitum pugnare".

17 Por isso, nota Pedro Calafate (2013-2014, p.122), Vieira escreve "salvações", no plural: "Há assim uma salvação a que se referem mais comumente os teólogos, aquela que resulta do processo de conversão dos infiéis e os encaminha ao seio da Igreja, conduzindo-os à 'perfeita salvação', isto é, à vida eterna no Céu e à visão bem-aventurada da divindade. Essa é a salvação dos fiéis. Mas há também uma salvação dos gentios, como eram os índios, antes da pregação dos portugueses e espanhóis, que, embora seja 'imperfeita e reduzida a metade, é a que basta para compassivamente salvar da pena eterna do sentido os mesmos infiéis que vivem e morrem na sua infidelidade sem culpa, por invencível ignorância do mesmo deus"”.

18 Durante o ano 1653, em carta ao príncipe D. Teodósio (Vieira, 1928, I, p.290-3), em duas cartas ao padre André Fernandes (Vieira, 1928, I, p.294-8 e 299-300) e em outra ao Provincial do Brasil, Francisco Gonçalves (Vieira, 1928, I, p.316-55). Ver ainda a carta a D. João IV, de 6 de abril de 1654 (Vieira, 1928, I, p.431-41).

19 Aristóteles define a servidão natural em Politica, 1254a-1255a.

20 "O domingo passado, falando na linguagem da terra, celebraram os brancos a sua festa do Rosário, e hoje, em dia e ato apartado, festejam a sua os pretos, e só os pretos" (Vieira, 1945-1948, XII, p.85).

21 Donde a referência aos filhos de Coré (Vieira, 1945-1948, XI, p.305). No Sermão da Epifania, pregado na Capela Real em 1662, ele afirma: "Um Etíope, se se lava nas águas do Zaire, fica limpo, mas não fica branco; porém, na água do Batismo sim, uma coisa e outra" (ibidem, II, p.48).

22 Vieira aceita, porém, a revolta dos índios, baseado em premissas diversas das que aplica aos africanos. É após a missão à Serra de Ibiapaba que, em 1662, ele fez uma crítica severa da cumplicidade do Estado português, da Igreja e inclusive dos próprios jesuítas na perda ilegítima de domínio dos índios. Assim lemos no Sermão da Epifania: "nós não só consentimos que os pobres gentios que convertemos percam tudo isto, senão que os persuadimos que o percam. [...] nós não só consentimos que percam a sua pátria aqueles gentios, mas somos os que à força de persuasões e promessas (que se lhes não guardam) os arrancamos de suas terras, trazendo povoações inteiras a viver ou a morrer junto das nossas. [...] e nós não só consentimos que aqueles gentios percam a soberania natural com que nasceram e vivem isentos de toda a sujeição; mas somos os que sujeitando-os ao jugo espiritual da Igreja, os obrigamos também, ao temporal da Coroa, fazendo-os jurar vassalagem" (Vieira, 1945-1948, II, p.46-7).

23 Em carta dirigida à Câmara de Belém do Pará pouco antes da expulsão do Maranhão, Vieira argumentava que os resgates de índios do sertão não eram suficientes para suprir a demanda por esta mão-de-obra, e propunha a sua substituição por escravos de Angola: "E vindo ao remédio, que se aponta dos escravos [índios] do sertão, posto que eu o aprovo muito, e o solicitei com El-rei, insistindo S. M. que todos fossem livres, vejo porém que o dito remédio por si só não é suficiente; porque, por mais que 
sejam os escravos que se fazem, muitos mais são sempre os que morrem, como mostra a experiência de cada dia neste Estado, e o mostrou no do Brasil, onde os moradores nunca tiveram remédio, senão depois que se serviram com escravos de Angola, por serem os índios da terra menos capazes de trabalho e de menos resistência contra as doenças, e que, por estarem perto das suas terras, mais facilmente ou fogem ou os matam as saudades delas" (Vieira, 1928, I, p.580-1). Vieira ainda voltou a propor a substituição de índios por negros em 1662, em 1669 e em 1678 (Vieira, 1951, p.2989, 318-19 e 336-7, respectivamente).

24 Segundo Tomás de Aquino, todos os outros preceitos da lei natural estão baseados neste princípio básico. Suma teológica, I-II, q.94, a.2.

\section{Referências}

ABBEVILLE, N. S. d'. Le Bresil, dont la coste est possedée par les Portugais et divisée en quatorze capitanieries [sic]... Par N. Sanson d'Abbeville, Geographe Ordinaire du Roy. Paris: Chez l'Autheur, 1657.

ACOSTA, J. de, S.J. De procuranda indorum salute. Madrid: CSIC, 1984-1987.

História natural y moral de las Indias, en que se tratan las cosas notables del cie-

lo, y elementos, plantas, y animales dellas; y los ritos, cerimónias, leyes y govierno y guerras de los Indios. Ed. Edmundo O’Gorman. México: Fondo de Cultura Económica, 1940.

AZEVEDO, J. L. História de António Vieira. Lisboa: Clássica, 1992.

BÍBLIA de Jerusalém. São Paulo: Paulus, 2017.

CALAFATE, P. Introdução. A Clavis Prophetarum no contexto do pensamento de Vieira. In: Obra completa do Padre António Vieira. 30v. Coordenação de Pedro Calafate e José Eduardo Franco. Lisboa: Círculo de Leitores, 2013-2014. t.III, v..V. p.57-136.

CLAUDINO-SALES, V.; LIRA, M. V. Megageomorfologia do noroeste do Estado do Ceará, Brasil. Caminhos da Geografia, Uberlândia, v.12, n.38, p.200-9, jun. 2011.

COLOMBO, E. Un gesuita inquieto. Carlo Antonio Casnedi (1643-1725) e il suo tempo. Soveria Mannelli: Ruberttino Editore, 2006.

LEI que se passou pelo Secretário de Estado em 9 de Abril de 655 sobre os índios do Maranhão. In: Anais da Biblioteca Nacional do Rio de Janeiro. Rio de Janeiro, Divisão de Obras raras e publicações, 1948. LXVI, p.25-28.

LEITE, A. S., S.J. História da Companhia de Jesus no Brasil. Lisboa, Portugália, 19381950.

1957-1968. $5 \mathrm{v}$.

MOLINA, L. de, S.J. De justitia et jure (1594). Coloniae: Agrippinae, 1613-1614.

Tratado da justiça e do direito. Debates sobre a justiça, o poder, a escravatura e a guerra. Lisboa: Fundação Calouste Gulbenkian, 2012.

MONTENEGRO, A. de la P., Bispo de Quito. Itinerario para Párrocos de Indios, en que se tratan las materias más particulares tocantes a ellos para su buena Adminsitración (1668). Madrid: En la Oficina de Pedro Marín, 1771. 
NAVARRO, E. de A. Dicionário de tupi antigo: a língua indígena clássica do Brasil, São Paulo: Global, 2013.

PÉCORA, A. Para ler Vieira: as 3 pontas das analogias nos sermões. FLOEMA. Caderno de Teoria e História Literária, v.I, n.1, p.29-36, 2005.

PUENTE, J. de la, O.P. La conveniencia de las dos monarquias católicas, la de la Iglesia Romana y la del Imperio español, y defensa de la precedencia de los Reyes Católicos de España a todos los Reyes del Mundo. Madrid: en la Imprenta Real, 1612.

SOlÓRZANO PEREIRA, J. de. Política indiana. Madrid: en la Officina de Diego Díaz de la Carrera, 1647.

. De indiarum iure. Madrid: CSIC, 1994. 4v.

SUÁREZ, F. de, S.J. De Legibus. Madrid: CSIC, 1967. 8v.

. Tractatus de legibus ac Deo legislatore. Madrid: Instituto de Estudios Políticos, 1967-1968. 6v.

TOMÁS de AQUINO, O. P. Suma teológica. São Paulo: Loyola, 2001-2003. 9v.

VIEIRA, A., S.J. Cartas do Padre António Vieira. Coordenadas e anotadas por João Lúcio de Azevedo. Coimbra: Imprensa da Universidade, 1928. 3v.

Sermões. Porto: Livraria Lello e Irmão, 1945-1948. 15v.

$\frac{}{\text { índios). }}$. Obras escolhidas. Lisboa: Sá da Costa, 1951. v.V (obras várias em defesa dos

. Clavis prophetarum. Resumo que dela escreveu o P. Carlos Antônio Casnedi. In: Obras escolbidas. Lisboa: Sá da Costa, 1953. v.IX (História do Futuro II) p.173-267.

Clavis Prophetarum. Chave dos Profetas. Livro III. Ed. de Arnaldo do Espírito Santo. Lisboa: Biblioteca Nacional, 2000.

WRIGHT, R.; CUNHA, M. C. da. Destruction, resistance and transformation. Southern Coastal, and Northern Brazil (1580-1890). In: SALOMON, F.; SCHWARTZ, S. (Ed.) The Cambridge history of the native peoples of the Americas. Cambridge: Cambridge University Press, 1996-2000. p.287-381.

ZERON, C. Linha de fé. A Companhia de Jesus e a escravidão no processo de formação da sociedade colonial (Brasil, séculos XVI e XVII). São Paulo: Edusp, 2011.

From farce to tragedy. Antonio Vieira's hubris in a war of factions. Journal of Jesuit Studies, v.2/3, p.387-420, 2015.

Antônio Vieira e os "escravos de condição": os aldeamentos jesuíticos no contexto das sociedades coloniais. In: FERNANDES, E. B. B. A Companhia de Jesus e os indios. Curitiba: Prismas, 2016. p.235-62.

Different Perceptions on the Topic of Forced Conversion, after the South Atlantic Experience. In: LAVENIA, V.; PASTORE, S.; PAVONE, S.; PETROLINI, C. Compel People to Come In. Violence and Catholic Conversions in the non-European World. Roma: Viella, 2018. p.49-68.

ZERON, C.; COLOMBO, E.; MASSIMI, M.; ROCCA, A. (Org.) Schavitù del corpo e schiavitù dell'anima. Chiesa, potere politico e schiavitù tra Atlantico e Mediterraneo (sec. XVI-XVIII). Roma: Bulzoni; Milano: ITL-Biblioteca Ambrosiana, 2018. p.13965 . 
RESUMO - A Igreja cristã foi constituída no contexto de expansão do Império Romano, do qual a escravidão era um fundamento importante. Apesar de seu discurso redentor, ela aceitou e integrou a escravidão em sua doutrina e instituições. Mas, foi com base na doutrina agostiniana da escravidão que a Igreja se adaptou a uma conjuntura propriamente escravista, nos tempos modernos, quando o trabalho compulsório tornou-se não apenas um elemento central na reprodução de diferentes sociedades ocidentais, mas também um elemento de articulação entre essas sociedades, por meio do tráfico. Neste artigo, comentamos alguns textos do Padre Antonio Vieira que, trabalhando no maior centro escravista do mundo, no século XVII, recolheu as sínteses de teólogos e juristas, distinguindo e qualificando suas posições por meio de uma análise contextual.

PALAVRAS-CHAVE: Antonio Vieira, Direito natural, Escravidão, Tapuias, Império português.

ABSTRACT - The Christian Church was constituted in the context of an expanding Roman Empire, in which slavery was an important foundation. In spite of her redemptive discourse, she accepted and integrated slavery into her doctrine and institutions. It was on the basis of the Augustinian doctrine of slavery that the Roman Church adapted to a slavish situation in modern times, when compulsory labor became not only a central element in the reproduction of different Western societies, but the slave trade also became an element of articulation between these societies. In this article, we comment on some texts by Father Antonio Vieira who, working in the world's largest slave center in the seventeenth century, collected the syntheses of theologians and jurists, distinguishing and qualifying their positions through contextual analysis.

KErWORDS: Antonio Vieira, Natural right, Slavery, Tapuias, Portuguese empire.

Carlos Zeron é professor titular do Departamento de História da Faculdade de Filosofia, Letras e Ciências Humanas da Universidade de São Paulo e diretor da Biblioteca Brasiliana Guita e José Mindlin. É autor de Linha de fé. A Companhia de Jesus e a escravidão no processo de formação da sociedade colonial (Brasil, séculos XVI e XVII) (Edusp, 2011; Honoré Champion, 2009) e outros. @ - zeron@usp.br /

https://orcid.org/0000-0002-2137-3362

${ }^{\text {I }}$ Faculdade de Filosofia, Letras e Ciências Humanas, Universidade de São Paulo, São Paulo, Brasil.

Recebido em 26.6.2019 e aceito em 22.7.2019. 